УДК [342.56 (477):341.21]"19/20

DOI 10.37566/2707-6849-2021-3(36)-9

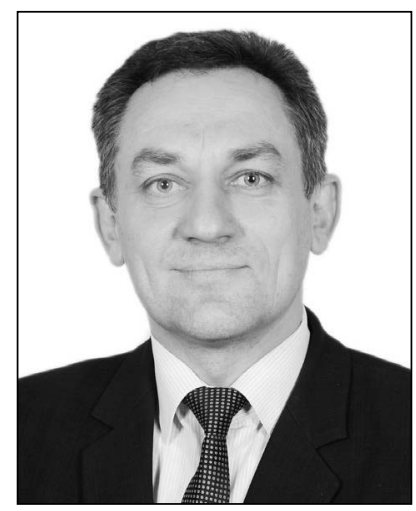

\title{
Степан БІлостоцький,
}

доцент кафедри давньої історії України та архівознавства Львівського національного університету імені Івана Франка, кандидат юридичних наук, доцент

\section{КОНТИНУЇТЕТ СУДОВОї ВЛАДИ В КОНТЕКСТІ СУЧАСНОГО УКРАЇНСЬКОГО ДЕРЖАВОТВОРЕННЯ}

Актуальність теми. Процес сучасного українського державотворення нерозривно пов'язаний з тисячолітньою історичною традицією українського народу. Суд як складова публічної влади в суспільстві має давню історію, що пов'язана із загальноцивілізаційними та національними процесами. Статус суду, складової державної влади, в різні історичні періоди визначався звичаями, правовими актами, конституціями з часу їх прийняття. Здійснюючи функцію захисту прав, він водночас забезпечував збереження історичної пам'яті - суспільного феномену, необхідного в соціальній практиці для виживання спільноти.

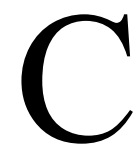

аме історична пам'ять творить зв'язок минулого і сьогодення, а історія розриває цей зв’ язок. Доки існують інституції, які зберігають традиції, доти немає потреби фіксувати історичну пам'ять письмово - писати історію. Інституціями, що впродовж століть оберігали історичну пам'ять українців, які перебували в складі інших держав, були суди. Завдяки діяльності місцевих судів елементи руського права часів Київської Русі, Галицько-Волинської держави, Великого князівства Литовського, Гетьманщини застосовувалися на практиці до середини XIX століття. 
Початком новітнього періоду в історії українського державотворення вважають проголошення Декларації про державний суверенітет України як верховенства, самостійності, повноти і неподільності влади Республіки в межах іiі території та незалежність і рівноправність у зовнішніх зносинах, а також поділу влади на законодавчу, виконавчу та судову [1].

324 серпня 1991 року відкрилася в історії українського державотворення нова сторінка - трансформації колишньої квазідержави, що називалася Українська Радянська Соціалістична Республіка (УРСР), на повноцінну самостійну, демократичну, правову державу під назвою - Україна [2].

Метою цієї статті $є$ дослідження ролі та місця судової влади в процесі новітнього періоду українського державотворення. Дослідження акцентує на важливості участі судової влади, іiі представників у процесі становлення та розвитку демократичних суспільних інституцій, захисту основоположних прав і свобод людини, соціальних цінностей та національних історичних традицій.

Питання державотворення були предметом дослідження вітчизняних правників, істориків, зокрема, В. Бігуна, О. Бориславської, С. Головатого, М. Оніщука, М. Козюбри, В. Речицького, П. Стецюка, В. Шаповала, Т. Гунчака, Я. Грицака, В. Смолія, С. Кульчицького.

Утвердження правової держави, у якій не тільки гарантуються, а й реально забезпечуються права і свободи людини та громадянина, неможливе без незалежного суду. На сучасному етапі державотворення питання функціонування судової влади серед політиків вважалося одним з пріоритетних $[3,4,5]$.

Визначальною властивістю судової влади в демократичній правовій державі єіï самостійність, що означає інституційну відокремленість від органів законодавчої та виконавчої влади, неприпустимість впливу останніх на виконання суддями їх професійних функцій, у тому числі й у спосіб не зумовленої суспільними прагненнями законодавчої реорганізації, зміни системи судоустрою [6]

Судова влада, як вид державної влади, є політичним явищем і визнається важливою складовою демократичного суспільства, іï незалежність гарантує захист ліберальних прав і свобод. Помилково ії ототожнювати з органами (носіями) цієї влади. Суди не належать виключно державі, можуть формуватися безпосередньо народом, який виступає джерелом державної влади, або за участю створених ним органів. На політичну сутність судової влади вказує те, що вона свої завдання реалізує, головним чином, від імені держави, народу чи короля при монархічних правліннях.

Окрім здійснення правосуддя, виконує функцію судового контролю за діяльністю політичних суб'єктів держави - парламентом, главою держави, урядом, партіями [7]. 3 огляду на це незалежні суди стають додатковим елементом політичної конфронтації, своєрідним відкритим публічним простором, в якому опозиція отримує додаткову можливість довести перевищення або зловживання чинної влади [7, s. 37]. 
Принцип інституційної безперервності означає, що органи державної влади, встановлені Основним Законом України, продовжують функціонувати в інтересах Українського народу та реалізовувати свої повноваження, виконувати завдання і функції, визначені у Конституції України, незалежно від цих змін, якщо тільки цими змінами не передбачено істотну (докорінну) зміну їх конституційного статусу, у тому числі їх ліквідацію [6].

У радянській Україні судова влада, державний арбітраж перебували під контролем і впливом командно-адміністративної системи колишнього Радянського Союзу $[8$, c. 30]. Попри те, і в ці часи суди були місцем відновлення законності, захисту порушених прав і свобод громадян, а судді усіх рівнів розглядали сотні позовів, відновлюючи порушені права.

Судді Верховного Суду України брали активну участь у розробленні Закону «Про реабілітацію жертв політичних репресій на Україні». Станом на 2001 рік було переглянуто 307 тис. 450 рішень органів позасудового винесення вироків - так званих особливих трійок НКВС, які складалися з начальника підрозділу НКВС, секретаря обкому партії та прокурора. Реабілітовано 248 тис. 710 осіб. Судді стали учасниками творення нових державних органів незалежної України.

Так, Віталій Бойко, тоді майбутній Голова Верховного Суду України (1994-2002), відкривав перше пленарне засідання Верховної Ради України першого скликання, на якому вручав посвідчення про обрання на посаду першому Президенту України Леоніду Кравчуку, та оголосив на засіданні Верховної Ради України офіційні результати референдуму з питання незалежності України. Завдяки його зусиллям як міністра юстиції (1990-1992) були розроблені проєкти законів «Про власність», «Про економічну самостійність України», затверджено Концепцію судово-правової реформи [9, с. 467].

Концепція стала першим концептуальним документом, у якому використано системний підхід до питання реформування судової системи з метою формування незалежної судової влади шляхом перебудови судової системи, створення нового законодавства, вдосконалення форм судочинства; передбачала реформу не тільки судів, а й прокуратури, адвокатури та органів юстиції; визначала види судів, які мають бути створені та їх компетенцію - Конституційний, загальні та арбітражні суди; передбачалося запровадження адміністративного судочинства, метою якого мав стати розгляд спорів між громадянином і органами державного управління [10].

Недоліками Концепції вважали відсутність термінів виконання [11, с. 140].

Судова реформа в Україні реалізовувалась шляхом фрагментарних змін чинного радянського законодавства, шляхом приведення діючого та створення нового законодавства до існуючих суспільних реалій.

Були внесені зміни до Конституції (Основного Закону) Української РСР (1978), якими закріплювався принцип верховенства законів УРСР на території республіки 
та створення Конституційного Суду УРСР, надання Верховному суду УРСР права найвищого судового контролю і нагляду за діяльністю судів, закріплено принцип позапартійності суддів [12].

Встановлено, що закони Української РСР та інші акти, ухвалені Верховною Радою Української РСР, діють на території України, оскільки вони не суперечать законам України, ухваленим після проголошення незалежності України; суди та арбітражні суди, сформовані на підставі Конституції (Основного Закону) Української РСР, діють в Україні до створення судів та арбітражних судів на підставі нової Конституції України [13].

Арбітражним судам надано статус органів судової влади, що здійснюють правосуддя в господарських відносинах як спеціалізованих судових установ [14].

Змінено Конституцію - запроваджено систему господарських судів: Вищий арбітражний суд Української РСР, арбітражні суди Кримської АРСР, областей та міста Києва становили єдину систему арбітражних судів України [14].

На законодавчому рівні закріплено принцип незалежності та недоторканності суддів, їх позапартійності та заборону входити до складу органів виконавчої влади, інших державних органів, органів місцевого самоврядування, підприємств, які мають на меті отримання прибутку, займатись підприємницькою діяльністю, крім викладацької, наукової та іншої оплачуваної творчої діяльності у вільний від роботи час [15].

Важливим етапом у розвитку державотворення було ухвалення Закону «Про Конституційний Суд України» [16] та призначення Головою Суду Леоніда Юзькова (1992-1996). Однак політичні інтереси не дали змоги сформувати склад суду для початку роботи.

У період політичної кризи та дії Конституційного договору 1995 року суди продовжували виконувати важливу державну функцію - захист прав і законних інтересів громадян, юридичних осіб і держави [17].

Важливим етапом у розвитку України стало прийняття Конституції 1996 року, згідно з якою судова влада визнана незалежною гілкою влади на рівні з виконавчою та законодавчою. Суду в Конституції відведено важливу роль у системі вищої державної влади та функціонування держави. По-перше, приведення Президента України до присяги здійснюється Головою Конституційного Суду України, по-друге, неможливість виконання повноважень за станом здоров'я та в порядку імпічменту Президента повинні підтверджуватися висновком Верховного Суду України [18].

За висловлюванням судді Верховного Суду США Богдана Футея, незалежна судова влада потребує тільки одного - незалежності [19]. Тому вся діяльність судової влади в Україні була спрямована на забезпечення цієї незалежності, яку завжди прагнули обмежити дві інші гілки влади. 
Для прикладу, у 1999 році Конституційний Суд України за конституційним поданням Верховного Суду України визнав неконституційними положення Закону України «Про Державний бюджет України на 1999 рік» у частині надання повноважень Кабінету Міністрів України здійснювати обмеження видатків з Державного бюджету України на утримання судових органів України. Питання неналежного фінансування було актуальним і в наступні роки. Станом на 2004 рік на діяльність судів виділялося коштів приблизно 40 \% від потреби.

Попри це, завдяки позиції Верховного Суду України вдалося покласти край політичній кризі, забезпечити суспільний спокій під час подій Помаранчевої Революції. Йдеться про унікальне та безпрецедентне за своїм характером рішення суддів Верховного Суду України від 03 грудня 2004 року про встановлення результатів виборів, яким уперше політична криза була вирішена на підставі конституційного принципу - верховенства права [20].

Політична боротьба в парламенті після набрання чинності Законом України «Про внесення змін до Конституції» (2222-IV) негативно вплинула на подальшу історію українського державотворення та незалежність судової влади.

Так, Голова Верховного Суду у відставці Віталій Бойко, коментуючи ці події, відмітив, що законодавчий орган блокує рішення Президента, рішення з'їзду суддів, які призначили суддів [21]. У 2006 році робота Конституційного Суду була заблокована - не ухвалено жодного рішення.

Цього ж року Голова Верховного Суду України Василь Маляренко звернувся листом до Президента Віктора Ющенка, в якому визнав неприпустимим звинувачувати судову систему в глибокій корумпованості: «Дискредитація судової системи серед людей сіє зневіру у можливість захистити себе, свої права та законні інтереси в суді» [22].

Рада суддів України, захищаючи суддівську незалежність, відзначила, що поширення заяв, «котрі ображають суддів України і завдають шкоди їх честі та гідності, не спряє існуванню неупередженого судочинства, підтриманню авторитету суду і держави, а також упевненості суспільства у спроможності судів захистити права і свободи громадян та державні інтереси» [23].

У 2007 році Рада суддів України звернулася до Президента України та Верховної Ради України в справі оцінки проєктів законів «Про судоустрій України» $\mathrm{i}$ «Статус суддів», наголосивши, що розгляд законопроєктів у Верховній Раді повинен відбуватися з урахуванням позиції суддівського корпусу з ключових питань; збільшення кількості судових органів і суддів шляхом реалізації принципу спеціалізації судової діяльності невиправдано ускладнить судову систему, зробить іiі малозрозумілою; позбавлення Верховного Суду касаційної функції, необхідних засобів для забезпечення однакового застосування законів судами, організаційної та процесуальної 
єдності судової системи призведе до його істотного послаблення та втрати ним важелів впливу на правозастосовну діяльність судів [24].

Неоднозначно оцінено суддями рішення Конституційного Суду України 2010 року, яким встановлено, що конституційний статус Верховного Суду України не передбачає наділення його законодавцем повноваженнями суду касаційної інстанції щодо рішень вищих спеціалізованих судів, які реалізують повноваження касаційної інстанції [25].

У 2016 році змінами до Конституції України та новим Законом України «Про судоустрій і статус суддів» була започаткована комплексна судова реформа. Зокрема, замість трьох вищих судів і Верховного Суду України створено єдиний Верховний Суд.

Конкурс до нового Верховного Суду був відкритим, унікальним та прозорим, 3 високим рівнем конкуренції, який проходив під дуже пильним наглядом громадськості, з прискіпливою перевіркою кандидатів антикорупційними органами.

Процес відбору суддів до Верховного Суду позитивно оцінений міжнародними експертами. Над даний час ця інституція користується високою довірою серед громадян.

Поряд $з$ тим, на переконання Конституційного Суду України, при створенні нового Верховного Суду був порушений принцип інституційної безперервності конституційного органу державної влади. Вилучення слова «України» $з$ власної назви держави - із словесної конструкції «Верховний Суд України» не вплинуло на конституційний статус цього органу державної влади [6].

Заслуговує на увагу в питаннях сучасного державотворення діяльність Вищої ради правосуддя, основним завданням якої $є$ забезпечення незалежності судової влади, iii функціонування на засадах відповідальності, підзвітності перед суспільством, формування доброчесного та високопрофесійного корпусу суддів.

У 2020 році за результатами розгляду законопроєктів, пов'язаних з правосуддям, Вищою радою правосуддя прийнято 44 рішення про затвердження консультативних висновків, з яких не підтримано законопроєктів - 18 (у 2019 році - 2). У березні 2021 року Вища рада правосуддя прийняла рішення звернутися до Верховної Ради України з пропозицією щодо невідкладного приведення положень чинного законодавства України щодо Верховного Суду України у відповідність до Рішення Конституційного Суду України № 2-р/2020 від 18 лютого 2020 року - щодо умов фінансового забезпечення діяльності Верховного Суду України, зокрема, в частині дотримання фінансових гарантій незалежності суддів та соціальних гарантій працівників його апарату.

Однак, незважаючи на успіхи в реформуванні судової влади, Україна отримала негативні рішення Європейського суду з прав людини у справі «Олександр Волков проти України» [26], «Гуменюк та інщі проти Украӥни» [27]. 
Отже, процес державотворення триває, судова влада змінюватиметься. Суди були та залишаються активними учасниками державотворчих процесів в Україні. На різних історичних етапах їх роль була відмінною: охоронці історичної пам'яті та звичаєвого права українців, учасники національно-визвольних змагань ХХ століття та творці демократичної судової влади, співучасники творення правових актів про незалежність України, захисники прав і свобод людини, а також миру і злагоди в українському суспільстві. Незалежність суду - це те, що судді повинні плекати та обстоювати. Незалежність суду є гарантією демократичного розвитку держави. Захист прав людини через верховенство права - формула, яку суди повинні застосовувати у своїй діяльності, бо лише так зможуть забезпечити до себе довіру та підтримку громадянським суспільством. Категорично негативного ставлення громадян до судової влади ніколи не існувало та не існує. Тому можна зробити припущення, що громадяни перебували у стані очікування від судової влади ініціатив та практичних кроків назустріч суспільним вимогам по реформуванню правосуддя.

\section{Перелік використаних джерел}

1. Декларачія про державний суверенітет від 16.07.1990 № 55-XII. Відомості Верховної Ради УРCP. 1990. № 31. Cm. 429. URL: https://zakon.rada.gov.ua/laws/ show/55-12\#Text.

2. Акт проголошення незалежності Украӥни. Постанова Верховної Ради Української РСР Про проголочення незалежності України від 24 серпня 1991. URL: https://zakon.rada.gov.ua/laws/show/1427-12\#Text

3. Стратегія сталого розвитку «Україна - 2020», схвалена Указом Президента України від 12 січня 2015 року № 5/2015. URL: https://www.president.gov.ua/ documents/52015-18245.

4. Стратегія розвитку системи правосуддя та конституційного судочинства на 2021-2023 роки, схвалена Указом Президента Украйни від 11 червня 2021 року № 231/2021. URL: https://www.president.gov.ua/documents/2312021-39137

5. Украӥна - 2030. Стратегія зміни майбутнього. Національний інститут стратегічних досліджень. URL: https://niss.gov.ua/sites/default/files/2020-12/ ukraine-2030-1.pdf.

6. Рішення Конституційного Суду України у справі за конституційним поданням Верховного Суду України щодо відповідності Конституиії України (конституційності) окремих положень пунктів 4, 7, 8, 9, 11, 13, 14, 17, 20, 22, 23, 25 розділу ХІІ «Прикінщеві та перехідні положення» Закону Украйни «Про судоустрій і статус суддів» від 2 червня 2016 року № 1402-VIII від 18 лютого 2020 року № 2-р/2020. URL: http://www.ccu.gov.ua/docs/3033

7. Skrzypiński Dariusz. Władza sąownicza w procesie transformacji polskiego systemu politycznego. Studium politologiczne. Wrocław, 2009. 
8. Футей Богдан. Обговорення проекту нової Конституиії України (Доповідь на Світовому Конгресі юристів, 9 жовтня 1992 року, м. Київ, Україна). Становлення правової держави в Україні 1991-2011. Київ: Юрінком Інтер, 2011.

9. Бірюков Олександр. Судова влада в сучасній Украӥні. Transformacja w Polsce i na Ukrainie. Wybrane aspekty / red. A. Antozsewskiego, A. Kolodii, K. Kowalczyka. Wroctaw, 2010.

10. Концепиіл судово-правової реформи в Україні, затверджена постановою Верховної Ради України 28 квітня 1992 року. URL: https://zakon.rada.gov.ua/laws/ show/2296-12\#Text

11. Хотинська-Нор О. 3. Теорія і практика судової реформи в Україні. Монографія. Київ, 2016.

12. Про зміни і доповнення до Конституиії (Основного Закону) Української РСР: Закон Украӥнської РСР від 24 жовтня 1990 року № 404-XII.

URL: https://zakon.rada.gov.ua/laws/show/404-12\#Text

13. Про правонаступництво: Закон України від 12 вересня 1991 року. URL: https://zakon.rada.gov.ua/laws/show/1543-12\#Text

14. Про арбітражний суд: Закон України від 4 червня 1991 року № 1142-XII. URL: https://zakon.rada.gov.ua/laws/show/1142-12/ed19921215\#Text

15. Про статус суддів: Закон України від 15 грудня 1992 року № 2862-XII. URL: https://zakon.rada.gov.ua/laws/show/2862-12/ed19921215\#Text

16. Про Конституиійний Суд Украӥни: Закон України від 13 липня 2017 року № 2136-VIII.

URL: https://zakon.rada.gov.ua/laws/show/2400-12\#Text

17. Конституиійний договір між Верховною Радою Украйни та Президентом України про основні засади організації та функціонування державної влади і місиевого самоврядування в Украӥні на період до прийняття нової Конституції Украйни. URL: https://zakon.rada.gov.ua/laws/show/1\%D0\%BA/95-\%D0\%B2\%D1\%80\#Text

18. Конституиія України, прийнята на п'ятій сесї̈ Верховної Ради Украӥни 28 червня 1996 року. URL: https://zakon.rada.gov.ua/laws/show/254\%D0\%BA/96$\% D 0 \% B 2 \% D 1 \% 80 \# T$ Text

19. Футей Богдан. Перспективи судової гілки як рівної серед рівних гілок влади. Становлення правової держави в Україні 1991-2011. Київ: Юрінком Інтер, 2011.

20. Рішення Верховного Суду України від 03 грудня 2004 року. URL: https://zakon. rada.gov.ua/laws/show/n0090700-04\#Text.

21. Бойко Віталій. Відсутність Конституційного суду -не панащея від скасування політичної реформи. 23 травня 2006. URL: https://www.unian.ua/politics/5538-vitaliyboyko-vidsutnist-konstitutsiynogo-sudu-ne-panatseya-vid-skasuvannya-politichnojireformi.html

22. Лист Голови Верховного Суду Украӥни В. Т. Маляренка Президенту Украӥни В. А. Ющенку. Вісник Верховного Суду України. 2006. № 6 (70). С. 7-8.

23. Заява Ради суддів Украйни від 26.05.2006. Вісник Верховного Суду України. 2006. № 6 (70). C. 9. 
24. Звернення Ради суддів Украӥни до Президента Украӥни та Верховної Ради України про проекти законів України «Про судоустрій Украӥни» $i$ «Про статус суддів» від 09.02.2007. URL: https://zakon.rada.gov.ua/rada/show/n0002414-07\#Text

25. Рішення Конституиійного Суду України у справі за конституційним поданням 46 народних депутатів України щзодо офіційного тлумачення термінів «найвищий судовий орган», «вищий судовий орган», «касаиійне оскарження», які містяться у статтях 125, 129 Конституиії України від 11 березня 2010 року № 8-pn/2010. URL: https://zakon.rada.gov.ua/laws/show/v008p710-10\#Text

26. Рішення Європейського суду з прав людини у справі «Олександр Волков проти України» (заява № 21722/11) від 9 січня 2013. URL: https://zakon.rada.gov.ua/laws/ show/974_947\#Text

27. Рішення Європейського суду з прав людини у справі «Гуменюк та інші проти Украӥни» (заява № 11423/19) від 21 липня 2021. URL: https: //hudoc.echr.coe.int/ eng\#\{\%22itemid\%22: [\%22001-211125\%22]\}.

\section{References}

1. Declaration of State Sovereignty dated 16.07.1990 № 55-XII. Data of Supreme Council of Ukrainian Soviet Socialist Republic (Verkhovna Rada of UkrSSR), 1990, № 31, art.429. URL: https://zakon.rada.gov.ua/laws/show/55-12\#Text[ukr].

2. The Declaration of Independence of Ukraine. Resolution of Supreme Council of Ukrainian Soviet Socialist Republic (Verkhovna Rada of UkrSSR) about the Declaration of Independence of Ukraine dated August 24, 1991. URL: https://zakon.rada.gov.ua/ laws/show/1427-12\#Text [ukr].

3. Presidential Decree of Ukraine «Sustainable development strategy «Ukraine 2020» from January 12, 2015 № 5/2015 [ukr].

4. Presidential Decree of Ukraine «Strategy for the development of the justice system and constitutional justice for 2021 - 2023» dated June 11, 2021 № 231/2021, URL: https://www.president.gov.ua/documents/2312021-39137 [ukr].

5. Ukraine - 2030. Strategy for changing the future. National Institute for Strategic Studies. URL: https://niss.gov.ua/sites/default/files/2020-12/ukraine-2030-1.pdf [ukr].

6. Judgement of the Constitutional Court of Ukraine in the case of constitutional submission of the Supreme Court of Ukraine regarding compliance of individual provisions of the Constitution of Ukraine of clauses 4, 7, 8, 9, 11, 13, 14, 17, 20, 22, 23, 25 of the section XII «Final and transitional provisions» of Law of Ukraine «about judicial system and judge status» dated June 2, 2016 № 1402-VIII from February 18, 2020 № 2-p/2020. URL: http://www.ccu.gov.ua/docs/3033 [ukr].

7. Skrzypiński Dariusz. Władza sadownicza w procesie transformacji polskiego systemu politycznego. Studium politologiczne. Wrocław, 2009.[pl.] 
8. Bohdan A. Futey. Discussion of the project of the new Constitution of Ukraine (Reportat the World Congress of the lawyers, $9^{\text {th }}$ October 1992, Kyiv, Ukraine). Formation of the rule of law in Ukraine 1991-2011. Kyiv: Yurinkom Inter, 2011.[ukr.]

9. Oleksandr Biryukov. Modern Ukrainian judiciary. Transformacja w Polsce i na Ukrainie. Wybrane aspekty/red. A. Antozsewskiego, A. Kolodii, K. Kowalczyka. Wroctaw, 2010 [ukr].

10. The concept of judicial reform in Ukraine, approved by the resolution of the Supreme Council of Ukraine (Verkhovna Rada of Ukraine), dated April 28, 1992.

URL: https://zakon.rada.gov.ua/laws/show/2296-12\#Text [ukr].

11. Hotynska-Nor O. Z. Theory and practice of judicial reform in Ukraine. Monograph. Kyiv, 2016 [ukr].

12. Law of Ukrainian Soviet Socialist Republic «about changes and additions to the Constitution (main Statute) of Ukrainian Soviet Socialist Republic» dated October 24, 1990 № 404-XII. URL: https://zakon.rada.gov.ua/laws/show/404-12\#Text [ukr].

13. Law of Ukraine about succession dated September 12, 1991. URL: https://zakon.rada.gov.ua/laws/show/1543-12\#Text[ukr].

14. Law of Ukraine «about arbitration court» dated June 4, 1991 № 1142-XII. URL: https://zakon.rada.gov.ua/laws/show/1142-12/ed19921215\#Text [ukr].

15. Law of Ukraine «about judge status» dated December 15, 1992 № 2862-XII. URL: https://zakon.rada.gov.ua/laws/show/2862-12/ed19921215\#Text [ukr].

16. Law of Ukraine «about constitutional court of Ukraine». URL: https://zakon.rada.gov.ua/laws/show/2400-12\#Text [ukr].

17. Constitutional Agreement between Supreme Council of Ukraine (Verkhovna Rada of Ukraine) and the President of Ukraine about main principles of organization and functioning of state power and local government in Ukraine for the period until the acceptance of the new Constitution of Ukraine. URL: https://zakon.rada.gov.ua/laws/ show/1\%D0\%BA/95-\%D0\%B2\%D1\%80\#Text [ukr].

18. Constitution of Ukraine accepted on the fifth session of the Supreme Council of Ukraine (Verkhovna Rada of Ukraine) on $28^{\text {th }}$ June 1996. URL: https://zakon.rada.gov. ua/laws $/$ show $/ 254 \% D 0 \% B A / 96-\% D 0 \% B 2 \% D 1 \% 80 \#$ Text [ukr].

19. Bohdan A. Futey. Prospects for the judiciary as an equal among equal branches of government. Formation of the rule of law in Ukraine 1991-2011. Kyiv: Yurinkom Inter, 2011. [ukr.]

20. Judgement of the Supreme Court of Ukraine dated December 032004. URL: https://zakon.rada.gov.ua/laws/show/n0090700-04\#Text [ukr].

21. Vitaliy Boyko. Absence of the Constitutional Court-is not a panacea for the abolition of political reform dated May 26, 2006. URL: https://www.unian.ua/politics/5538-vitaliyboyko-vidsutnist-konstitutsiynogo-sudu-ne-panatseya-vid-skasuvannya-politichnojireformi.html [ukr]. 
22. Letter of the head of Supreme Court of Ukraine V. T. Malarenko to the President of Ukraine V. A. Yushchenko. Visnyk of supreme court of Ukraine, 2006, № 6 (70). C. 7-8 [ukr].

23. Statement of the Council of Judges of Ukraine dated 25.06.2006, Visnyk of supreme court of Ukraine, 2006, № 6 (70), p. 9 [ukr].

24. Appeal of the Council of Judges of Ukraine to the President of Ukraine and Supreme Council of Ukraine (Verkhovna Rada of Ukraine) about draft law of Ukraine «about judicial system of Ukraine» and «about judge status» dated 09.02.2007.

URL: https://zakon.rada.gov.ua/rada/show/n0002414-07\#Text [ukr].

25. Judgement of the Constitutional Court of Ukraine in the case of constitutional submission of 46 deputies of Ukraine regarding official interpretation of the next terms "the highest judicial authority», "supreme judicial authority», "cassation appeal», contained in the articles 125, 129 of the Constitution of Ukraine from March 11, 2010 № 8-pn/2010. URL: https://zakon.rada.gov.ua/laws/show/v008p710-10\#Text [ukr].

26. Judgment of the European Court of Human Rights in the case of Oleksandr Volkov v. Ukraine (application № 21722/11) dated January 9, 2013.

URL: https://zakon.rada.gov.ua/laws/show/974_947\#Text [ukr].

27. Judgment of the European Court of Human Rights in the case of Gumenyuk and others v. Ukraine (application № 11423/19) від 21 линня 2021.

URL: https: //hudoc.echr.coe.int/eng\#\{\%22itemid\%22: [\%22001-211125\%22]\}. [engl.]

\section{БІЛОСТОЦЬКИЙ С. Континуїтет судової влади в контексті сучасного украӥнського державотворення.}

У статті висвітлюються питання становлення та участі судової влади в процесі державотворчих процесів у новітньому періоді історичного розвитку України. Окреслено історичні події, учасниками яких були представники судової влади та які пов'язані зі становленням, розвитком демократичних суспільних інституцій, захистом основоположних прав і свобод людини, соціальних цінностей та національних історичних традицій. Наголошено на тому, що демократичний розвиток держави можливий лише за належного функціонування незалежного суду.

Ключові слова: принции інституційної безперервності, незалежність, суверенітет, суд, судова влада, Верховний Суд Украӥни, Конституційний Суд Украйни.

\section{БИЛОСТОЦКИЙ С. Континуитет судебной власти в контексте развития современного украинского государства.}

В статье освещаются вопросы становления и участия судебной власти в процессе развития украинского государства в новейшем периоде исторического развития Украины. Определены исторические события, участниками которых были 
представители судебной власти и которые связаны со становлением, развитием демократических общественных институтов, защитой основных прав и свобод человека, социальных ценностей и национальных исторических традиций. Отмечено, что демократическое развитие государства возможно только при деятельности независимых судов.

Ключевые слова: принцип институциональной непрерывности, независимость, суверенитет, суд, судебная власть, Верховный Суд Украины, Конституционный Суд Украины.

\section{BILOSTOTSKYJS. Continuity of the judiciary in the context of modern Ukrainian state formation.}

The article covers the issues of formation and participation of the judiciary in the process of state-building in the latest period of historical development of Ukraine. The historical events which were attended by representatives of the judiciary and which are related to the formation, development of democratic social institutions, protection of fundamental human rights and freedoms, social values and national historical traditions. It is noted that judicial reform in Ukraine was implemented through fragmentary changes in current Soviet legislation, by bringing existing and creating new legislation to existing social realities. An important stage in Ukraine's development was the adoption of the Constitution in 1996, according to which the judiciary was recognized as an independent branch of government among the executive and legislative branches. In the constitution, for the court is assigned an important role in the system of supreme state power and the functioning of the state. First, the President of Ukraine is sworn in by the Chairman of the Constitutional Court of Ukraine, secondly, the impossibility of exercising powers due to health and impeachment of the President must be confirmed by the conclusion of the Supreme Court of Ukraine. It is emphasized that political conflicts in a democratic society should be resolved exclusively in the legal field. A clear example is the events of the Orange Revolution in 2004, when the Supreme Court of Ukraine put an end to the political crisis and ensured public peace by issuing a court decision on the election results, first applying to the constitutional principle of the rule of law. It is noted that an important participant in modern statehood is an independent constitutional body of state power and judicial governance - the High Council of Justice, whose main task is to ensure the independence of the judiciary, its functioning on accountability, accountability to society, formation of a virtuous and highly professional body of judges.

Key words: principle of institutional continuity, independence, sovereignty, court, judiciary, Supreme Court of Ukraine, Constitutional Court of Ukraine. 